\title{
The mammalian clock component PERIOD2 coordinates circadian output by interaction with nuclear receptors
}

\author{
Isabelle Schmutz, ${ }^{1}$ Jürgen A. Ripperger, ${ }^{1}$ Stéphanie Baeriswyl-Aebischer, and Urs Albrecht ${ }^{2}$ \\ Department of Medicine, Unit of Biochemistry, University of Fribourg, 1700 Fribourg, Switzerland
}

\begin{abstract}
Mammalian circadian clocks provide a temporal framework to synchronize biological functions. To obtain robust rhythms with a periodicity of about a day, these clocks use molecular oscillators consisting of two interlocked feedback loops. The core loop generates rhythms by transcriptional repression via the Period (PER) and Cryptochrome (CRY) proteins, whereas the stabilizing loop establishes roughly antiphasic rhythms via nuclear receptors. Nuclear receptors also govern many pathways that affect metabolism and physiology. Here we show that the core loop component PER2 can coordinate circadian output with the circadian oscillator. PER2 interacts with nuclear receptors including PPAR $\alpha$ and REV-ERB $\alpha$ and serves as a coregulator of nuclear receptor-mediated transcription. Consequently, PER2 is rhythmically bound at the promoters of nuclear receptor target genes in vivo. In this way, the circadian oscillator can modulate the expression of nuclear receptor target genes like Bmal1, Hnf1 $\alpha$, and Glucose-6-phosphatase. The concept that PER2 may propagate clock information to metabolic pathways via nuclear receptors adds an important facet to the clock-dependent regulation of biological networks.
\end{abstract}

[Keywords: Circadian oscillator; transcription; protein-protein interaction]

Supplemental material is available at http://www.genesdev.org.

Received October 27, 2009; revised version accepted December 21, 2009.

Many changes in physiology and behavior occur rhythmically with a period length of $\sim 24 \mathrm{~h}$, even in the absence of external timing cues. These circadian oscillations are generated by autonomous clock mechanisms that can be synchronized to environmental cues such as the daynight cycle. In mammals, circadian oscillations can be observed in most cells and tissues, where they play a role in the temporal organization of biochemical and physiological functions. Due to the cell-autonomous character of the circadian clock, a central coordinator is necessary to establish a stable phase relationship between the different tissue clocks. The main coordinator of all body clocks resides in the suprachiasmatic nucleus (SCN), a structure in the ventral part of the hypothalamus. This brain region perceives light information from the environment and subsequently synchronizes all peripheral clocks to generate coherent systemic rhythms for the entire organism (Liu et al. 2007).

The mammalian circadian oscillator is based on a pair of transcriptional activators-BMAL1/MOP3 (Hogenesch et al. 1998; Bunger et al. 2000) and CLOCK (or NPAS2 in the brain) (King et al. 1997; Reick et al. 2001; DeBruyne

\footnotetext{
${ }^{1}$ These authors contributed equally to this work.

${ }^{2}$ Corresponding author.

E-MAIL urs.albrecht@unifr.ch; FAX 41-26-300-9735.

Article is online at http://www.genesdev.org/cgi/doi/10.1101/gad.564110.
}

et al. 2007a,b) — and at least two classes of transcriptional repressors that maintain two distinct regulatory loops. In the stabilizing loop, the nuclear receptor REV-ERB $\alpha$ accumulates rhythmically to repress the expression of various circadian genes, including Bmal1 and Clock (Preitner et al. 2002; Ueda et al. 2002). Originally supposed to be a transcriptional activator (Harding and Lazar 1993), REV$\mathrm{ERB} \alpha$ was later identified as a genuine transcriptional repressor that interacts with the corepressor N-CoR 1 and the histone deacetylase HDAC3 to maintain a repressive state (Downes et al. 1996; Yin and Lazar 2005). The repressive action of REV-ERB $\alpha$ is periodically counterbalanced by the nuclear receptor $\operatorname{ROR} \alpha$, and in the liver by PPAR $\alpha$, to yield rhythmic gene expression (Sato et al. 2004; Canaple et al. 2006).

In the core loop, circadian regulation of target genes is mediated via so-called E-box motifs, which are specific binding sites for BMAL1 and CLOCK. Complexes of PERIOD (PER) and CRYPTOCHROME (CRY) proteins perform repression of BMAL1- and CLOCK-mediated transcription (Gekakis et al. 1998; Griffin et al. 1999; Kume et al. 1999|. Upon reaching a certain threshold concentration, the PER proteins together with the CRY proteins repress their own transcription and that of other circadian genes, including the ReV-Erb $\alpha$ gene. Two mammalian homologs of the Drosophila per gene important for mammalian circadian rhythms have been identified 
(Albrecht et al. 1997; Shearman et al. 1997; Sun et al. 1997; Tei et al. 1997). Manipulation of Per gene expression and activity in the mouse demonstrated a role for these genes in the circadian oscillator (Zheng et al. 1999, 2001; Bae et al. 2001; Cermakian et al. 2001). In analogy to the Drosophila feedback loop of circadian clock regulation (Hardin et al. 1990), the Per1 and Per2 genes were postulated to be negative regulators of the feedback loop in mammals without mechanistic distinction. However, there is evidence that PER1 and PER2 play nonredundant roles in the circadian clock; in particular, PER2 might act as a positive regulator (Zheng et al. 1999, 2001; Shearman et al. 2000).

The output from the circadian oscillator is mediated either by genes that are hardwired directly to the transcriptional network (Jin et al. 1999; Ripperger et al. 2000), or by rhythmically expressed transcriptional regulators as intermediaries (Ueda et al. 2005). Of recent interest is the family of nuclear receptors. More than half of the 49 mouse nuclear receptors display rhythmic mRNA accumulation patterns in many different phases, allowing for the rhythmic control of energy, glucose, and lipid metabolism (Yang et al. 2006). The nuclear receptors REV-ERB $\alpha$, $\operatorname{ROR} \alpha$, and PPAR $\alpha$ are implicated in the clock mechanism of the stabilizing loop (Preitner et al. 2002; Sato et al. 2004; Canaple et al. 2006; Liu et al. 2008). Other nuclear receptors have known functions for the rhythmic control of tissue-specific output processes (Yang et al. 2006). Coupling the expression of nuclear receptors directly to the transcriptional network would facilitate the temporal organization of the output processes under regular circumstances, but may be circuitous and inflexible in situations necessitating a rapid adaptation of the underlying transcriptional network to changes in the environment. Therefore, a mechanism modulating circadian nuclear receptor activity at the protein rather than the transcriptional level can be envisaged.

Exploring the differences between PER1 and PER2, we found that PER2 rather than PER1 acts as a coregulator of various nuclear receptors. This may explain many of the functional differences between the two PER proteins. In particular, the physical interaction of PER2 with PPAR $\alpha$ and REV-ERB $\alpha$ allows for a modulation of Bmal1 gene regulation and a precise coupling of the core and the stabilizing loop. Additionally, PER2 and nuclear receptors affect rhythmic transcription of output genes like $H n f 1 \alpha$ and Glucose-6-phosphatase involved in glucose homeostasis. Our results suggest that the physical interaction of PER2 with different nuclear receptors is a rapid means to modulate rhythmic gene expression, allowing the finetuning and optimization of cellular responses to environmental signals.

\section{Results}

Nuclear receptors form complexes with PER2

The PER proteins have the capability to interact with multiple proteins, but do not necessarily have the same binding partners. In addition to the known interaction partners, two classes of motifs have been described in the PER proteins (Albrecht et al. 2007) that resemble interaction motifs of nuclear receptors with their coregulators: the CoRNR and LXXLL motifs (Heery et al. 1997; $\mathrm{Hu}$ and Lazar 1999). The potential CoRNR motifs of both PER proteins are quite conserved; however, the sequences of the potential LXXLL motifs differ (Fig. 1A), presumably mediating different protein-protein interactions.

In accordance with the assumption that PER proteins could interact physically with nuclear receptors, PER2 coimmunoprecipitated with the upstream regulator of the Bmal1 gene, PPAR $\alpha$, from mouse liver nuclear extracts (Fig. 1B). This interaction was more pronounced at ZT20 (Zeitgeber time 20; ZT0 is lights on and ZT12 lights off), the time of high Bmal1 expression (see below), suggesting a role of this complex for the activation of the Bmal1 gene. In contrast, PER1 protein did not coimmunoprecipitate significantly with $\operatorname{PPAR} \alpha$ (Fig. 1B), although the known interaction with BMAL1 (Lee et al. 2001) was observed (Fig. 1C). In order to investigate further the physical interaction between PER2 and nuclear receptors, we supplemented mouse NIH 3T3 fibroblasts with an expression vector for V5-tagged PER2 and expression vectors for HA-tagged nuclear receptors. We selected representatives of various nuclear receptor subfamilies expressed in liver tissue based on either of two criteria: known influence on the circadian oscillator, or rhythmic expression in the phase of PER2 accumulation (Yang et al. 2006). We found that V5-tagged PER2 coimmunoprecipitated with REV-ERB $\alpha, \operatorname{PPAR} \alpha, \mathrm{HNF} 4 \alpha$, and $\mathrm{TR} \alpha$, and, to a lesser extent, with NURR 1 and $\operatorname{ROR} \alpha$ (Fig. 1D). No reproducible interaction was observed for the nuclear receptors $\mathrm{ER} \alpha$ and $\mathrm{RXR} \alpha$. The interaction of the same nuclear receptors with V5-tagged PER1 was much weaker (Supplemental Fig. 1A,B), although V5-tagged PER1 coimmunoprecipitated equally as well as V5-tagged PER2 with HA-CRY1 (Supplemental Fig. 1C).

The in vitro experiments indicate interaction of PER2 with REV-ERB $\alpha$, the transcriptional repressor of Bmall. Similarly, PER2 also coimmunoprecipitated REV-ERB $\alpha$ in mouse liver nuclear extracts (Fig. 1E). The observed coimmunoprecipitation was comparable with the one observed with BMAL1. However, the precipitates were observed roughly at the opposite time (ZT8 and ZT12) as compared with precipitates containing PPAR $\alpha$ (ZT20) (Fig. 1B,E; Supplemental Fig. 1D). In conclusion, both PER proteins interact with components of the core loop, whereas PER2 has the capacity to coimmunoprecipitate with some of our selected nuclear receptors.

\section{PER2 interacts with PPAR $\alpha$ or REV-ERB $\alpha$ via its LXXLL sequence motifs}

The differential interaction potential of the PER 1 and PER2 proteins with nuclear receptors may be rooted in the sequence of the LXXLL-like motifs found in these proteins (Fig. 1A). Replacement of the leucine residues by alanines in the $\mathrm{N}$-terminal but not in the C-terminal motif of PER2 abolished interaction with PPAR $\alpha$ (mLCCLL and mLLNLL) (Fig. 2A; Supplemental Fig. 2D) 
A

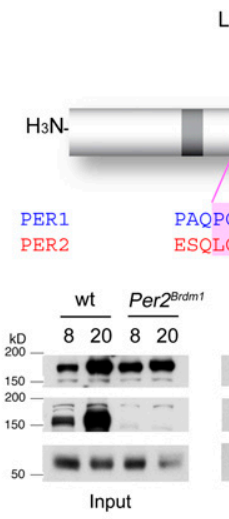

LXXLL

CORNR

| |

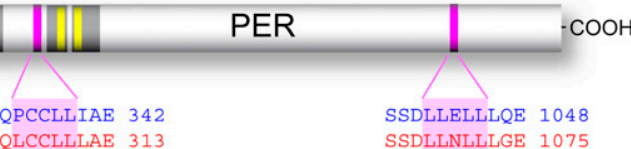

B

Input
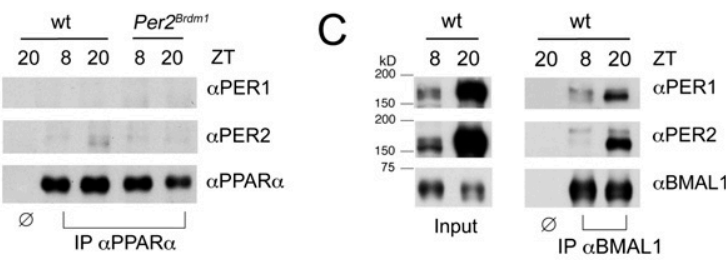

D
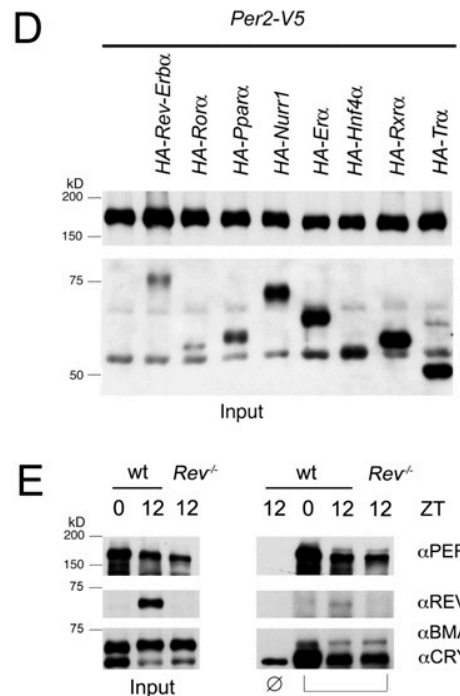

Input

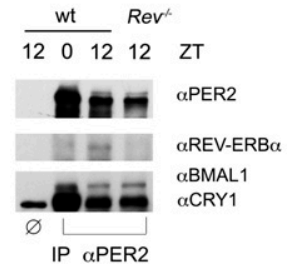

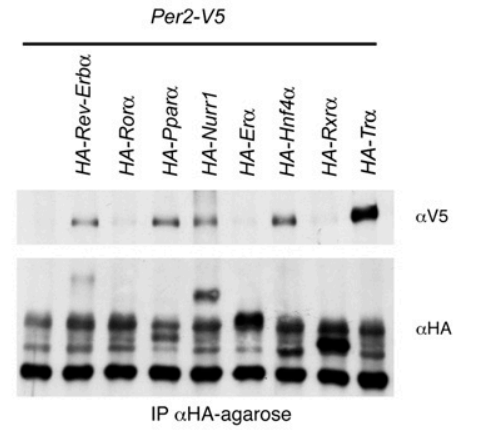

Figure 1. PER2 interacts with nuclear receptors. $(A)$ Structural organization of mouse PER proteins. Gray boxes represent the PAS A, PAS B, and PAC domains. Corepressor-like (CoRNR, yellow) and coactivator like (LXXLL, pink) protein-protein interaction motifs are highlighted. Alignment of the LXXLL sequences of PER1 (blue) and PER2 (red) is shown. Numbers indicate the amino acid positions in the primary structure. (B) PPAR $\alpha$ was immunoprecipitated from mouse liver nuclear extracts. Extracts derived from Per2 ${ }^{\text {Brdm1 }}$ mice were used to monitor the specificity of the antibody against PER2. (C) BMAL1 was immunoprecipitated from mouse liver nuclear extracts. (D) HA-tagged nuclear receptors were expressed in NIH 3T3 cells and were immunoprecipitated from nuclear extracts. Expression vectors used for cotransfection are indicated. $(E)$ PER2 was immunoprecipitated from mouse liver nuclear extracts. An extract derived from Rev-Erb $\alpha^{-1-}$ mice demonstrates the specificity of the antibody against REV-ERB $\alpha$. Immunoprecipitated proteins were detected by Western blot analysis with the indicated antibodies (on the right). The input is shown in the left panels. On the left side of the panels, the positions of marker bands are indicated (relative molecular weight). Reactions with beads and extract alone were used as controls for nonspecific binding. (ZT) Zeitgeber time.

to a comparable extent as the mutation of both LXXLL sequences (mLXXLL). This was not due to a general conformational change of the PER2 mutant proteins, because they could still bind to CRY1 (Supplemental Fig. 2A). Similarly, the interaction of PER2 with REV-ERB $\alpha$ relied on the $\mathrm{N}$-terminal motif but not the $\mathrm{C}$-terminal motif, as demonstrated by mutation and deletion analysis (Fig. 2B; Supplemental Fig. 2B,D). In conclusion, it appears that the N-terminal motif is involved mainly in the interaction between PER2 and nuclear receptors.

The specificity of interaction between LXXLL motifs and nuclear receptors is mediated partially by a conserved lysine residue in helix 3 of the ligand-binding domain (LBD) of nuclear receptors (Savkur and Burris 2004). Therefore, we replaced the corresponding lysine residue in helix 3 of REV-ERB $\alpha$ by an alanine. This mutation (K456A) reduced the potential of REV-ERB $\alpha$ to bind to PER2 by $\sim 60 \%$, and deletion of the entire LBD by $\sim 90 \%$ (Fig. 2C; Supplemental Fig. 2C,D). A similar point mutation in PPAR $\alpha$ (K292A), however, had less impact on the interaction with PER2, as did the deletion of its helix 12, which represents a second anchor point for LXXLL motifs of nuclear receptors (Fig. 2C; Supplemental Fig. 2D). While REV-ERB $\alpha$ has the potential to directly bind
PER2, our data suggest that $\operatorname{PPAR} \alpha$ may interact only indirectly with PER2, probably as a heterodimer with other nuclear receptors.

To assign a function to the LXXLL-like motifs, we investigated the impact of the PER proteins on the expression of Rev-Erbo or Bmal1 as genes regulated by the core or stabilizing loop, respectively. NIH 3T3 cells were transfected with adequate luciferase reporter genes, and the rhythmic bioluminescence of cultures was monitored continuously for multiple days. Cotransfection of either Per1 or Per2 reduced the activity of the Rev-Erb $\alpha$ luc reporter in a similar and dose-dependent fashion (Fig. 2D; Supplemental Fig. 2E,F). In contrast, the same amounts of either expression vector had divergent effects on the Bmal1 luc reporter (Fig. 2E). Cotransfection of increasing amounts of Per1 reduced the amplitude of Bmal1 luc expression, while increasing amounts of Per2 provoked a dose-dependent increase with dampened amplitude (Supplemental Fig. 2E,F). Surprisingly, the same mutations that weakened the interaction of PER2 with nuclear receptors converted the Bmal1 regulatory potential of PER2 into that of PER1 (Fig. 2E; Supplemental Fig. 2E). This may indicate that the LXXLL sequences in PER2 are important for the regulation of the Bmal1 gene. 
Schmutz et al.
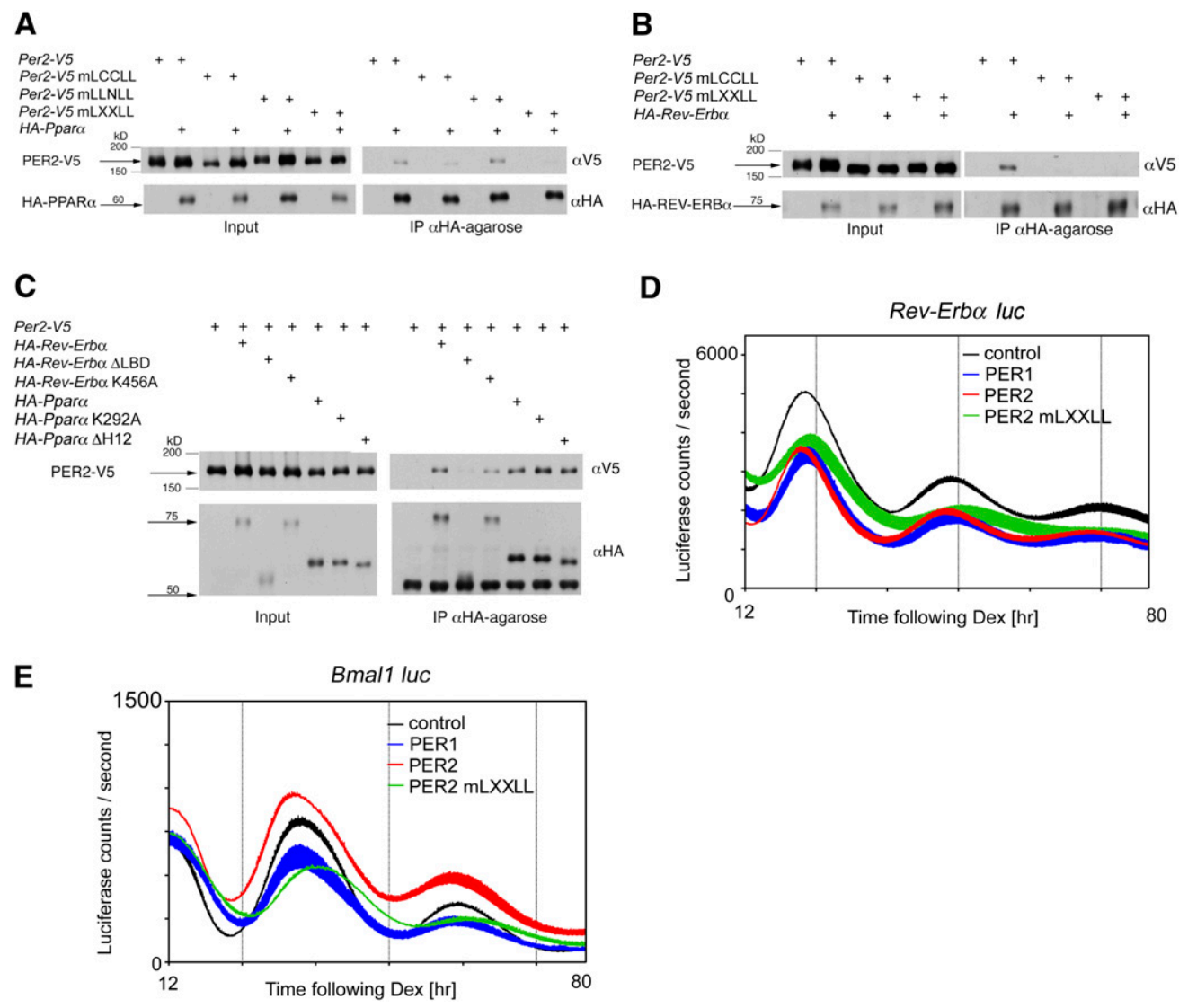

Figure 2. LXXLL-related motifs in PER2 are important for its physical interaction with nuclear receptors. $(A-C)$ Immunoprecipitation of HA-tagged PPAR $\alpha(A, C)$ or REV-ERB $\alpha(B, C)$ from NIH 3T3 nuclear extracts (see Fig. 1D). (mLCCLL) Mutation of N-terminal motif; (mLLNLL) mutation of C-terminal motif; (mLXXLL) mutation of $\mathrm{N}$ - and C-terminal motifs. $(D, E) \mathrm{NIH} 3 \mathrm{~T} 3$ cells were transfected with Rev-Erb $\alpha(D)$ or Bmal1 (E) luciferase reporter vector either alone or together with an expression vector for PER1 (blue), PER2 (red), or mutated PER2 (mLXXLL; green). Amounts of expression vectors were adjusted to yield similar repression of Rev-Erba luc. Cells were synchronized with dexamethasone, and luciferase activity of each culture was recorded. Data are plotted as mean \pm SD $(n=2$, representative experiment out of three independent experiments).

\section{PER2 binds in a REV-ERB $\alpha$-dependent fashion} to the Bmall promoter in vivo

If the complex of PER2 with nuclear receptors mediates transcriptional regulation, then the presence of both should overlap at the regulatory regions of their target genes. We used chromatin immunoprecipitation (ChIP) to investigate regulatory regions of circadian target genes in vivo. Both PER1 and PER2 were detected at the Rev-Erb $\alpha$ gene in a phase coinciding with the repression of this gene, and this binding was independent of REV-ERB $\alpha$ (Fig. 3A; Supplemental Fig. 3A). Surprisingly, we found that PER2 bound to the promoter region $(+50)$ of the Bmal1 gene in a phase coinciding with the repression of this gene (Fig. 3B; Supplemental Fig. 3A). Binding of PER2 overlapped with binding of REV-ERB $\alpha$ to the same region. The detection of PER2 was clearly dependent on the binding of the REV-ERB $\alpha$ protein, because in Rev-Erb $\alpha$-deficient mice, neither PER2 nor REV-ERB $\alpha$ was bound at the Bmal1 promoter. Binding of PER1 was not observed at this promoter. Similarly, binding of PER2 but not PER1 was observed at the upstream regulatory region $(-1600)$ of the Bmal1 gene containing binding sites for PPAR $\alpha$ (Fig. 3C; Canaple et al. 2006), or at the promoter region of the HNF $4 \alpha$-controlled Hnf1 $\alpha$ gene (Fig. 3D; Tian and Schibler 1991). In these cases, PER2 binding overlapped with PPAR $\alpha$ or HNF $4 \alpha$ and correlated with the activation or repression of these target genes, respectively (Fig. 3C,D; Supplemental Fig. 3A). As a control, binding of PER2 was not observed at any of these promoters in Per2 ${ }^{\text {Brdm1 }}$ mice (Supplemental Fig. 3B).

Taken together, we identified three different ways that PER2 can bind to promoters of circadian genes: (1) REV$\mathrm{ERB} \alpha$-dependent binding as observed on the Bmal1 promoter; (2) PPAR $\alpha$ or HNF $4 \alpha$ correlated binding, as seen for the upstream region of Bmal1 or the Hnf1 $\alpha$ promoter, respectively; and (3) BMAL1 correlated binding (Supplemental Fig. 3C), as evidenced on the Rev-Erb $\alpha$ promoter, a property that is shared by PER1. These results from ChIP experiments strongly favor our hypothesis that PER2 modulates gene expression not only via the known interaction with BMAL1, but also via interactions with nuclear receptors. Hence, due to these interactions, PER2 has much more regulatory potential than previously thought. 
A

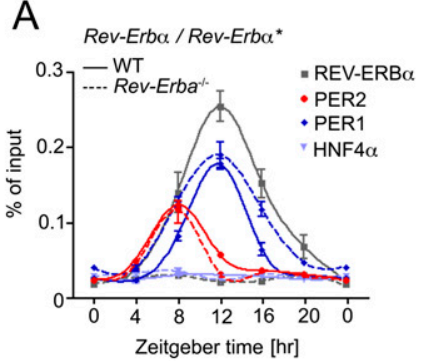

C

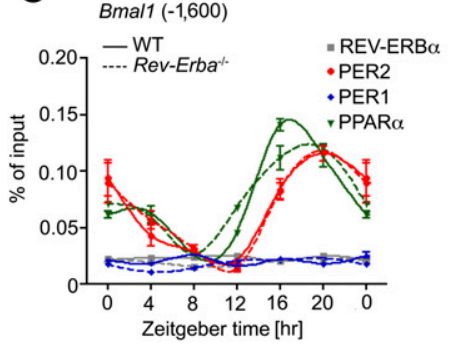

B

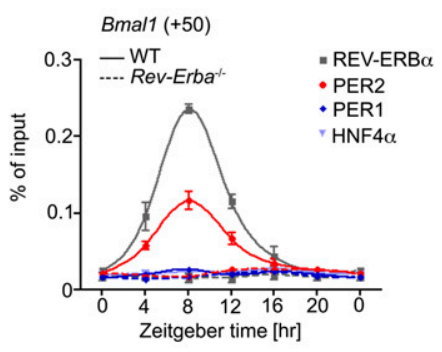

$\mathrm{D}$

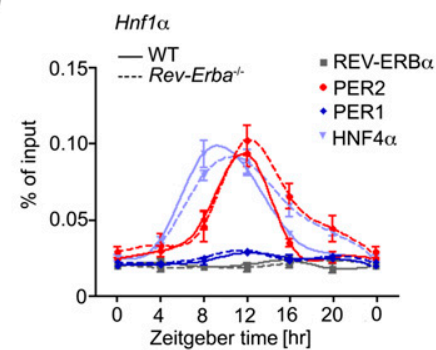

Figure 3. PER 2 binding to the regulatory regions of circadian target genes in vivo. $(A-D)$ Chromatin from wild-type (solid lines) and Rev-Erbo ${ }^{-/-}$mice (dashed lines) was prepared at 4-h intervals from mice held in a 12-h light/12-h dark cycle (LD 12:12). The binding of the indicated proteins to their regulatory region was analyzed by ChIP. Specific TaqMan probes were used to detect the Rev-Erb $\alpha$ promoter region $(A)$, the Bmall promoter region $(+50, B)$, the Bmal1 upstream regulatory region $(-1600, C)$, and the $H n f 1 \alpha$ promoter region $(D)$. Plotted are the mean values \pm SEM from three independent experiments; ZT0 is double-plotted. $\left(^{\star}\right)$ The regulatory region preceding the Rev-Erb $\alpha$ knockout allele.
PER2 and nuclear receptors modulate the expression of the Bmall gene in the liver

To assign a biological function to the interaction of PER2 with REV-ERB $\alpha$, we generated mice deficient for both genes and consequently lacking Per2 and Rev-Erb $\alpha$ mRNA expression (Supplemental Fig. 4A-C). Strikingly, in the liver of Rev-Erb $\alpha^{-/-} /$Per2 mutant animals, Bmal1 mRNA accumulation was no longer rhythmic (Fig. 4A). Instead, this gene was expressed at a constant level corresponding to the maximum of Bmal1 expression found in Per2 $2^{B r d m 1}$ mice on the one hand, and representing roughly the median of the rhythmic Bmal1 accumulation in Rev-Erbo ${ }^{-1-}$ mice on the other hand. These results suggest that, for the activation of the Bmall gene, the interaction of PER2 with REV-ERB $\alpha$ in vivo is not essential, and that at least one other interaction partner of PER2 exists that can synergistically regulate expression of the Bmal1 gene in the liver. A candidate could be $\operatorname{PPAR} \alpha$. Our results indicate that this nuclear receptor can be immunoprecipitated with PER2 in liver nuclear extracts (Fig. 1B). In addition, PPAR $\alpha$ and PER2 are found at the same time at the upstream regulatory region of the Bmal1 gene (Fig. 3C). To monitor a potential synergistic effect between PPAR $\alpha$ and PER2, we referred again to our in vitro fibroblast system. The original Bmal1 luciferase reporter construct (Bmal1 luc) (Nagoshi et al. 2004) does not contain PPAR $\alpha$ regulatory sites. Therefore, we extended this construct by 822 base pairs (bp) of upstream promoter sequence to include a PPAR $\alpha$ regulatory site (Canaple et al. 2006). This construct (Bmal1 ext. luc) displayed a threefold to fivefold higher magnitude of expression compared with the shorter construct /data not shown), indicating that, in these additional 822 bp, important elements for Bmal1 expression in fibroblasts are present. Surprisingly, $\operatorname{PPAR} \alpha$, together with its heterodimerization partner, $\mathrm{RXR} \alpha$, had only a slight enhancing effect on Bmal1 ext. luc reporter expression (Fig. 4B).
However, cotransfection of PER2 yielded a dose-dependent overall increase in reporter gene activity, which was dependent on functional LXXLL sequences in PER2. In concert with $\operatorname{PPAR} \alpha$ (and $\operatorname{RXR} \alpha$ ), PER2 appears to function as a coactivator under our in vitro conditions. In conclusion, the regulation of the Bmal1 gene in the liver is modulated by two circadian mechanisms: rhythmic repression by REV-ERB $\alpha$ (with a slight contribution of PER2), and rhythmic activation by other nuclear receptors that use PER2 as a coactivator, such as PPAR $\alpha$.

Although the mRNA accumulation of Bmal1 was found to be no longer rhythmic in Rev-Erbo ${ }^{-1-} /$ Per2 mutant mice, this did not have dramatic consequences on the cycling of components belonging to the core transcriptional feedback loop. The expression of Per1 (Fig. 4C), $D b p$, and Rev-Erb $\beta$ (Supplemental Fig. 4D,E) was rhythmic and in the same phase as found in Per2 ${ }^{\text {Brdm1 }}$ mice. The protein accumulation patterns of core clock proteins in liver nuclear extracts of the four different genotypes correlated with the mRNA patterns (Fig. 4A,C,D; Supplemental Fig. 4F). Furthermore, probably due to potential cofactors and/or post-translational modification of BMAL1 (Fig. 4D,E), its binding to the promoter of the Rev-Erbo gene was still rhythmic.

\section{PER2 and REV-ERB $\alpha$ are important for the coupling} of the core and stabilizing loop

Similar to the expression profile of Bmal1 in the liver (Fig. 4A), the expression of this gene under constant conditions in the SCN of ReV-Erb $\alpha^{-1-} /$ Per2 mutant mice was constitutive (Fig. 5A) at $\sim 95 \%$ of the peak levels compared with Bmal1 expression in wild-type and ReV-Erb $\alpha^{-/-}$. deficient mice. In addition, the expression of the core loop components Per1 and Cry1 was rhythmic (Fig. 5B,C). The difference of Bmal1 expression levels in liver and SCN tissue of ReV-Erb $\alpha^{-1-} /$ Per2 mutant mice $175 \%$ vs. $95 \%$ ) (Figs. 4A, 5A) indicates distinct tissue-specific 
A
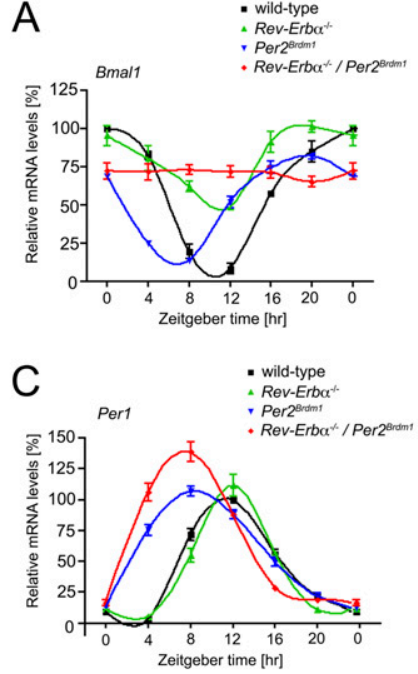

D

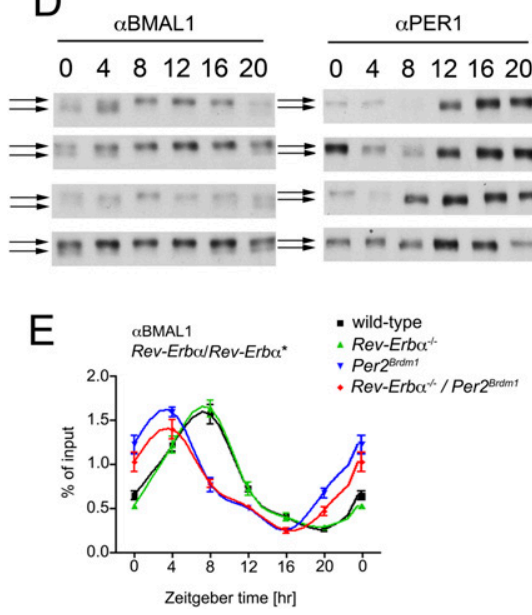

B
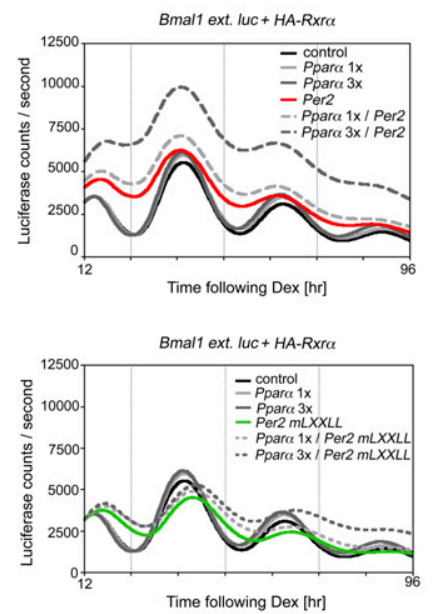

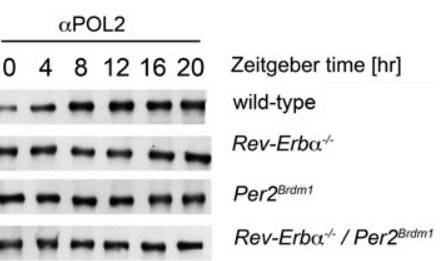

Figure 4. Constant expression of Bmal1 in livers of ReV-Erbo ${ }^{-1-} /$ Per2 mutant mice. Total RNA, protein extracts, and chromatin from wild-type (black), Rev-Erbo-l- (green), Per2 ${ }^{\text {Brdm1 } 1}$ (blue), and Rev$E r b \alpha^{-1-}$ Per2 mutant (red) animals maintained in LD 12:12 were prepared. $(A, C)$ The relative amounts of Bmal1 $(A)$ and Per1 $(C)$ mRNA were measured by TaqMan real-time RT-PCR. Plotted are the mean values \pm SEM from three independent experiments; ZT0 is double-plotted. $(B) \mathrm{NIH} 3 \mathrm{~T} 3$ cells were transfected with Bmal1 ext. luciferase reporter, $H A-R x r \alpha$ expression vector $(\mathrm{RXR} \alpha$ as a heterodimerization partner of PPAR $\alpha$ was used to enhance the effects of PPAR $\alpha$ ), and the indicated expression vectors. Cells were synchronized with dexamethasone, and bioluminescence was recorded. The top panel shows the cotransfections with Per2-V5 (red), and the bottom panel shows the cotransfections with mutated Per2-V5 (mLXXLL, green). Dashed lines or dotted lines represent cotransfections of the increasing amounts of HA-Ppar $\alpha$ together with the constant amount of Per2-V5 or mLXXLL-Per2-V5 expression vector, respectively. Amounts of expression vectors were adjusted to yield similar repression of Rev-Erb $\alpha$ luc (data not shown). Data are plotted as mean only l $n=2$, representative experiment out of three independent experiments). Note that the LXXLL sequences are involved in the activation of the reporter gene by PER 2 and PPAR $\alpha$. $(D)$ Nuclear extracts were analyzed by Western blot analysis using the indicated antibodies. Arrows indicate differently migrating forms of the corresponding protein. The accumulation of RNA polymerase II ( $\alpha$ POL 2$)$ is shown as a loading control. $(E)$ ChIP analysis with $\alpha$ BMAL1 using a specific TaqMan probe for the promoter region of the Rev-Erbo gene or the Rev-Erb $\alpha^{-1-}$ knockout allele $\left(R e v-E r b \alpha^{\star}\right)$ (mean \pm SEM from three independent experiments; ZTO is double-plotted). modulation of Bmal1 expression. We hypothesize that the tissue-specific effects on Bmal1 expression might be the result of the differential presence of PPAR $\alpha$ in liver and SCN tissue. This idea is in agreement with the ob- servation that PPAR $\alpha$ expression is not detected in the SCN (see Allen Brain Atlas, http://www.brain-map.org). It is tempting to speculate that other nuclear receptors might replace PPAR $\alpha$ function in the SCN. Taken
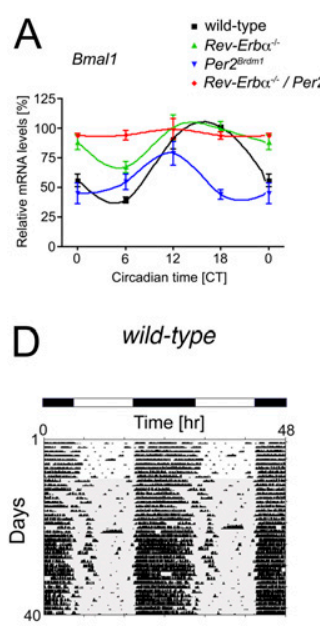

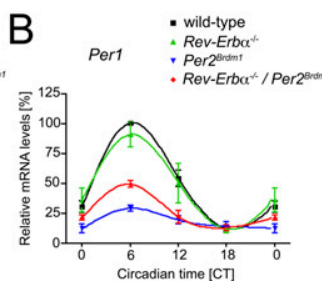

Rev-Erba $\alpha^{*}$ Per2 ${ }^{\text {Brdm1 }}$

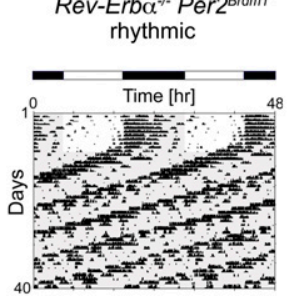

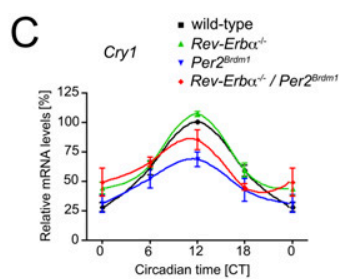

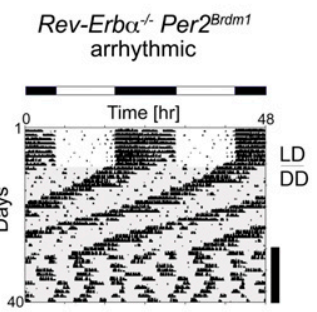

Figure 5. Analysis of circadian mRNA in the SCN and free-running activity of wild-type and $\mathrm{ReV}^{-}$ Erbo $\alpha^{-/-} /$Per2 mutant animals. $(A-C)$ Relative expression of Bmal1 $(A), \operatorname{Per} 1(B)$, and Cry1 $(C)$ mRNA in SCN tissue under constant (DD) conditions from wild-type (black), Rev-Erb $\alpha^{-l-}$ (green), Per2 ${ }^{\text {Brdm1 } 1}$ (blue), and Rev-Erbo-/-/Per2 mutant (red) animals as revealed by in situ hybridization. Plotted are the mean values \pm SEM from three independent experiments; CT0 is double-plotted. $(D)$ Representative locomotor activity records of wild-type, rhythmic, and arrhythmic Rev-Erb $\alpha^{-1-} /$ Per2 mutant animals as double plots. The top bar indicates two consecutive days, and the dark shaded areas represent phases of darkness. The side bar indicates the days when the animal displays arrhythmic locomotor activity. 
together, tissue-specific regulation of clock gene expression may be due to the presence of particular nuclear receptors in a given tissue (Yang et al. 2006) interacting with PER2.

An output of the central pacemaker in the SCN is circadian locomotor activity under free-running conditions (e.g., constant darkness). This can be measured using a wheel-running setup to monitor activity (Fig. 5D). Under these conditions, ReV-Erb $\alpha^{-/-} /$Per2 mutant mice had a significantly shorter period length compared with wild-type, Rev-Erbo ${ }^{-1-}$, and Per2 $2^{\text {Brdm1 }}$ mice (Supplemental Fig. 5A-C). In contrast to Per2 ${ }^{B r d m 1}$ animals, $50 \%$ of double-mutant animals showed a stable circadian rhythm throughout at least $5 \mathrm{wk}$ in constant darkness (Fig. 5D, middle panel). The other $50 \%$ of the animals lost their circadian rhythmicity when held in constant darkness for an average of $21 \mathrm{~d}$ (Fig. 5D, right panel). The ratio of rhythmic to arrhythmic animals was more or less constant, independent of gender or pedigree /data not shown). Interestingly, individual double-mutant mice could switch from arrhythmic to rhythmic behavior under prolonged constant conditions (Supplemental Fig. 5D). These behavioral changes could not be traced back to accidental exposure of the animals to an external Zeitgeber. Altogether, our data revealed two characteristics of the circadian behavior in $R e v-E r b \alpha^{-/-} /$Per2 mutant mice: First, double mutants have a very short freerunning period length; and second, the behavioral phenotype observed in Per2 $2^{B r d m 1}$ mice is partially rescued, possibly due to an increase of Bmal1 expression.

\section{Potential impact of PER2 and REV-ERBa on the glucose metabolism of the liver}

Nuclear receptors are involved in the rhythmic regulation of various metabolic pathways in the liver (Yang et al. 2006). We analyzed the function of PER2 on the expression of genes that have been described previously as targets of REV-ERB $\alpha$ and are involved in glucose metabolism (Yin et al. 2007; Le Martelot et al. 2009). The mRNA accumulation of the gluconeogenic enzyme Phosphoenolpyruvate-carboxykinase 1 (Pepck1) was circadian in the different genetic backgrounds (Fig. 6A) in a similar phase as the Per1, Dbp, and Rev-Erb $\beta$ genes (Fig. 4C; Supplemental Fig. 4D,E), suggesting that PER2 acts via BMAL1 and CLOCK on this gene and that PER1 can
A

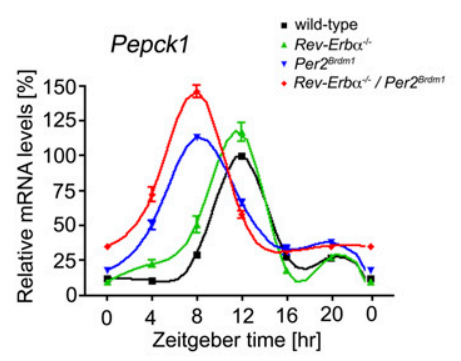

C

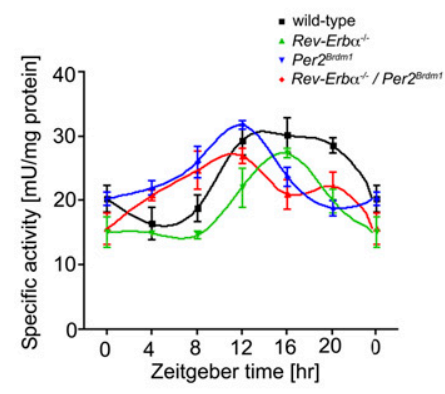

E

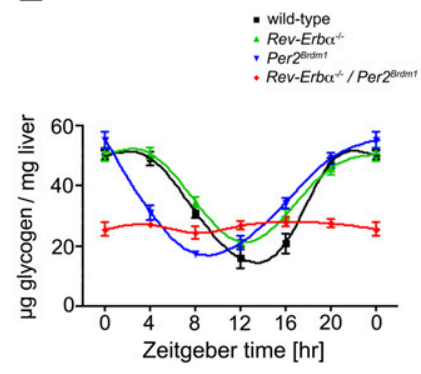

B

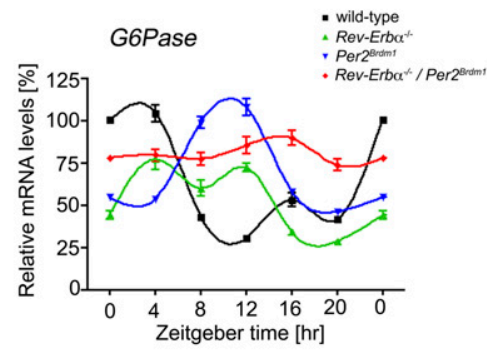

D

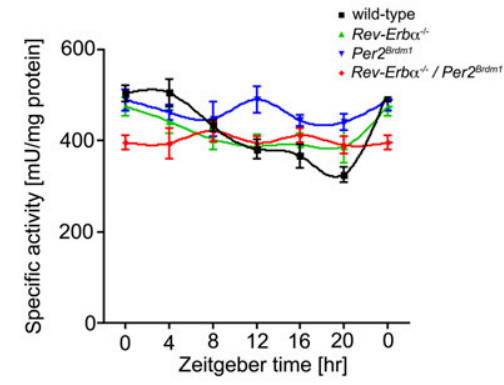

$\mathrm{F}$

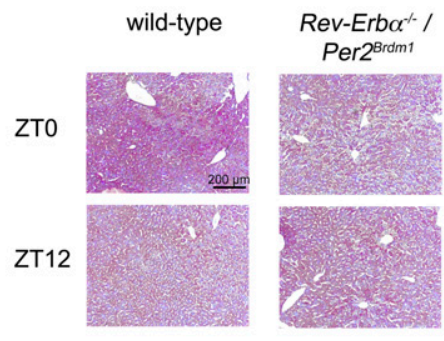

Figure 6. Rhythmic glycogen accumulation is abolished in Rev-Erb $\alpha^{-1-}$ Per2 mutant mice. $(A, B)$ mRNA analysis in liver. The relative amounts of Pepck $1(C)$ and G6Pase $(D)$ mRNA were measured by TaqMan real-time RT-PCR. (C) Cytosolic PEPCK activity. (D) G6Pase activity measured in liver microsomes. (E) Liver glycogen content. Values represent the mean \pm SEM. (F) PAS staining of liver tissue in wild-type and $R e v-E r b \alpha^{-/-} /$Per2 mutant animals at ZT0 and ZT12. Bar, $200 \mu \mathrm{m}$. Plotted are the mean values \pm SEM from three independent experiments derived from wild-type (black), Rev-Erb $\alpha^{-1-}$ (green), Per2 ${ }^{\text {Brdm1 }}$ (blue), and Rev-Erbo ${ }^{-/-}$/Per2 mutant (red) animals; ZT0 is double-plotted. 
compensate for the loss of PER2 function. In agreement with Le Martelot et al. (2009), we find only a minor effect of the deletion of Rev-Erb $\alpha$ on the regulation of the Pepck1 gene. However, the function of REV-ERB $\alpha$ could be compensated by REV-ERB $\beta$, since the $R e V-E r b \beta$ gene is still rhythmically expressed in all of our genetic backgrounds (Supplemental Fig. 4E).

In contrast to the rhythmic expression of the Pepck1 gene, the expression of a key enzyme of glucose metabolism, Glucose-6-phosphatase (G6Pase), was affected in ReV-Erb $\alpha^{-1-}$-deficient mice and Per2 ${ }^{\text {Brdm1 } 1}$ animals. However, this expression was constant in Rev-Erbo ${ }^{-/-} /$Per2 mutant mice (Fig. 6B), similar to the Bmal1 gene (Fig. 4A). At the promoter of the G6Pase gene, we could detect rhythmic PER2 binding in vivo (Supplemental Fig. 6A). This binding correlated with the transcriptional repression of this gene (Fig. 6B). However, based on the different mRNA accumulation patterns of Bmal1 and G6Pase, and the different kinetics of PER2 binding to the regulatory regions in vivo in the single-mutant mice, we conclude that PER2 mediates this transcriptional repression not via $\operatorname{REV}-E R B \alpha$, but another, yet to be specified, nuclear receptor.

It is tempting to speculate that PER2 couples different metabolic pathways (i.e., the BMAL1/CLOCK and nuclear receptor-driven ones). Without this coupling, there may occur a desynchronization of metabolic pathways in otherwise circadian liver cells, as observed, e.g., for the enzymatic activities of PEPCK and G6Pase in the doublemutant mice (Fig. 6C,D). This may have direct or indirect consequences on glucose metabolism in the liver. To address this point, we characterized hepatic functions of ReV-Erb $\alpha^{-/-}$Per2 mutant mice. In spite of normal patterns of food consumption (Supplemental Fig. 6B), steadystate levels of glycogen in the liver were blunted in $R e v-$ $E_{\text {Erb }}{ }^{-1-} /$ Per2 mutant mice (Fig. 6E,F). However, the molecular mechanism leading to this phenotype is complex. In addition to the temporal shift of Pepck 1 expression and the constant expression of G6Pase, the mRNA accumulation patterns of glucokinase, glycogen synthase, glycogen phosphorylase, phosphofructokinase, fructose-1, 6-bisphosphatase, and the glucose transporter Glut2 were deregulated in ReV-Erb $\alpha^{-/-} /$Per2 mutant mice (data not shown). Since the glycogen store can be used to stabilize the blood glucose concentration, it is not surprising that we observed a slight hypoglycemic state at ZT12 in these mice (Supplemental Fig. 6C) and also in Per2 ${ }^{\text {Brdm1 } 1}$ mice, which also display a glycogen accumulation phenotype (Fig. 6E). Taken together, our data point toward a function of PER2 to coordinate nuclear receptor-regulated pathways with the circadian oscillator.

\section{Discussion}

\section{Functional differences of PER1 and PER2}

Comparing PER1 and PER2 proteins, we identified a motif in PER2 that extends its regulatory capacity, most probably by interaction with nuclear receptors. Between the two PAS domains, which mediate the interaction with
BMAL1 and CLOCK, a potential LXXLL motif was identified. Substitution of its leucines by alanines or its deletion (data not shown) converted the Bmal1 regulatory potential of PER2 into that of PER1 (Fig. 2E; Supplemental Fig. 2E). However, replacing the LXXLL motifs of PER1 with the ones of PER2 did not convert PER1 into an activator of the Bmal1 gene (data not shown). Consequently, there may be further amino acids involved that mediate or prevent interactions necessary for the activation of the Bmal1 gene. Recently, a partial tertiary structure of PER2 was resolved containing both PAS domains (Hennig et al. 2009). In this structure, the LCCLL motif is embedded in a flexible linker region emerging from the PAS-A domain. One can speculate that the region between the two PAS domains could trigger interaction of PER2 with either BMAL1 and CLOCK, or nuclear receptors. The comparable region of PER1 may not be flexible enough or may not be accessible to allow both kinds of interactions. As a result, PER2 interacts much more strongly than PER1 with our selection of nuclear receptors (Supplemental Fig. 1A,B).

Even though LXXLL-like motifs are important for interaction of nuclear receptors with PER2, this kind of interaction may not follow classical coactivator/nuclear receptor interactions. REV-ERB $\alpha$ does not possess a C-terminal helix 12 necessary to stabilize interaction with a typical LXXLL motif (Savkur and Burris 2004). In spite of this, we could identify Lys 456 as important (Fig. 2C; Supplemental Fig. 2D). In many nuclear receptors, a comparable lysine directly interacts with the two neighboring leucine residues of the LXXLL motif or similar amino acids of the coregulator N-CoR1 (Hu and Lazar 1999; Savkur and Burris 2004). We can envision a similar function of this particular residue for the interaction of REV-ERB $\alpha$ with PER2. Other mutations of REV-ERB $\alpha-$ e.g., preventing the binding of the prosthetic heme group by a deletion of the last 28 amino acids $(\Delta \mathrm{C})$ (Supplemental Fig. 2C) or by a replacement of His 602 with phenylalanine (Raghuram et al. 2007), or preventing the binding of the corepressor N-CoR1 (six amino acids that directly contact $\mathrm{N}-\mathrm{CoR} 1$ replaced by alanines) (Woo et al. 2007)—did not abolish the interaction with PER2 (data not shown).

PER2 may function as a modulator of Bmal1 gene expression when complemented with nuclear receptors. Cotransfection of PER2 with PPAR $\alpha$ and $\operatorname{RXR} \alpha$ yielded a dose-dependent increase of Bmal1 activity (Fig. 4B), while cotransfection of REV-ERB $\alpha$ reduced the activation potential of PER2 (Supplemental Fig. 7, troughs). Since REV-ERB $\alpha$ recruits also the corepressor N-CoR1 for its repressive function (Harding and Lazar 1995) on the Bmal1 promoter (Yin and Lazar 2005), one could envisage a competition between PER2 and N-CoR1 for the same binding pocket in REV-ERB $\alpha$. This competition might be influenced by heme, because the activity of the REV$\mathrm{ERB} \alpha / \mathrm{N}-\mathrm{CoR} 1$ complex seems to be modulated by the presence of this ligand (Yin et al. 2007). In contrast, the interaction of REV-ERB $\alpha$ and PER2 is resistant to the depletion or augmentation of the endogenous heme pool in NIH 3T3 cells (Supplemental Fig. S8). At the moment, 
however, we cannot rule out that in vivo binding of heme might have a regulatory influence on the strength of this interaction, allowing integration of the metabolic state via the interaction of PER2 with REV-ERB $\alpha$.

\section{Dynamics of PER2 binding to regulatory regions of circadian clock and clock-controlled genes}

Our data suggest that PER2 can bind to many nuclear receptor target genes in vivo. Surprisingly, this binding correlated with the binding of several nuclear receptors and occurred in many different phases of the circadian cycle. It is tempting to speculate that post-translational modifications of PER2 or the nuclear receptors confer specificity to such interactions. We found two nuclear receptors in the regulatory regions of the Bmal1 gene in the liver: REV-ERB $\alpha$ and PPAR $\alpha$ (Fig. 3). At the promoter region, the rhythmic binding of REV-ERB $\alpha$ is in line with the hypothesis that it is a negative regulator of the Bmal1 gene (Fig. 3B; Preitner et al. 2002; Liu et al. 2008). At the upstream regulatory element, we found rhythmic binding of PPAR $\alpha$ in the phase of transcriptional activation (Fig. 3C; Canaple et al. 2006). However, we found evidence that PER2 contributes to the circadian regulation of this gene as well. PER2 bound to two distinct regions of the Bmal1 gene in two different phases (Fig. 3B,C). At the promoter, PER2 interacts with REV-ERB $\alpha$ in a phase that correlates with transcriptional repression and contributes $\sim 10 \%$ to the overall repression (Fig. 4A, trough). In contrast, at the upstream regulatory region, the binding of PER2 contributes $\sim 25 \%$ to the overall transcriptional activity (Fig. 4 A, peak). Most probably, this effect is mediated via PPAR $\alpha$. Our results show for the first time that PER2 binds at the Bmal1 regulatory region, and thereby has an influence on the magnitude and amplitude of Bmal1 expression.

From our genetic analysis, we conclude that PER2 may affect the regulation of the Hnf1 $\alpha$ gene in the liver (Supplemental Fig. 3A). We speculate that this effect might be mediated via $\mathrm{HNF} 4 \alpha$, because PER2 can be immunoprecipitated with this nuclear receptor (Fig. 1D) and both proteins are present at the same time at the Hnf $1 \alpha$ promoter (Fig. 3D). HNF1 $\alpha$ and HNF $4 \alpha$ are both transcription factors at the crossroads of glucose homeostasis. Mutations in those genes lead to maturity-onset diabetes in the young (MODY) (Yamagata et al. 1996a,b) caused by an insulin secretion defect. Hence, Per2 ${ }^{\text {Brdm } 1}$ mutant animals may show alterations in glucose homeostasis, as observed previously for Bmal1 and Clock mutant mice (Rudic et al. 2004; Lamia et al. 2008).

Binding of PER2 but also PER1 to the Rev-Erb $\alpha$ promoter is probably dependent on BMAL1 and CLOCK that bind to E-boxes (Lee et al. 2001). Interestingly, the peak of PER1 and PER2 binding to the regulatory region of RevErb $\alpha$ is 4-6 h after the peak of BMAL1 binding (Fig. 3A; Supplemental Fig. 3C). This may indicate that both PER proteins detach BMAL1 and CLOCK from their regulatory elements and that this contributes to the initiation of repression. A peculiar finding is the binding of REV-ERB $\alpha$ at its own promoter, because it does not interact with PER2, as observed at the Bmal1 promoter. We hypothesize that this difference is rooted in the usage of different DNA regulatory elements for REV-ERB $\alpha$ (Harding and Lazar 1993, 1995; Preitner et al. 2002; Ueda et al. 2002).

\section{Bistability of the circadian system} in Rev-Erb $\alpha^{-l-} /$ Per2 double-mutant mice

Our experiments with double-mutant mice suggest that both REV-ERB $\alpha$ and PER2 participate in the coordination of the oscillator in the SCN. Per2 ${ }^{\text {Brdm1 }}$ mice become arrhythmic in constant darkness (Supplemental Fig. 5A; Zheng et al. 1999). Interestingly, mice with a loss of RevErb $\alpha$ in the Per2 ${ }^{\text {Brdm } 1}$ mutant background can display circadian wheel-running behavior (Fig. 5D). This restoration of rhythmicity may be due to an increase of the Bmal1 mRNA in the SCN (Fig. 5A), probably leading to higher protein levels. However, the activity of BMAL1 has to be counterbalanced by appropriate amounts of components of the negative limb such as Per1 and Cry1. Previous experiments show that Per 1 and Cry 1 are sufficient to sustain oscillator function (Oster et al. 2002, 2003). However, expression levels of Per 1 and Cry 1 in the SCN of Rev-Erbo $\alpha^{-1-}$ Per2 mutant mice are lower compared with wild-type and Rev-Erb $\alpha^{-1-}$ mice (Fig. 5B,C), and those levels may not be able to maintain a stable oscillator. Therefore, one can assume that the doublemutant animals may not display rhythmic wheel-running behavior under all conditions. Accordingly, we found that Rev-Erbo ${ }^{-/-}$Per2 mutant mice can switch from rhythmic to arrhythmic behavior and vice versa (Fig. 5D; Supplemental Fig. 5D). We propose that this switch is linked to the levels of negative oscillator components that can fluctuate around a critical threshold. Taken together, constitutive high expression of Bmal1 in the SCN of double-mutant mice is not sufficient to generate a fully functional core loop, as manifested by reduced Per1 and Cry 1 levels and the observed behavioral alterations. This is in opposition to the situation found in the liver (Fig. 4) and tissue culture cells (Liu et al. 2008), where constantly elevated expression of Bmal1 leaves the oscillator functional.

\section{Coupling of metabolic pathways by PER2}

The metabolism is made up of anabolic and catabolic pathways. The circadian timing system regulates the temporal separation of these pathways in the liver (Panda et al. 2002; Storch et al. 2002) in order to optimize an organism's performance. Interestingly, nuclear receptors have been implicated in the circadian regulation of metabolically important genes (Yang et al. 2006). Since many nuclear receptors are not expressed with high circadian amplitude (Supplemental Fig. 4F; Yang et al. 2006), a regulatory mechanism based on nuclear receptors alone may be too imprecise to confer oscillator information to target genes. Our data indicate an additional regulatory mechanism conferring oscillator information based on protein-protein interactions. We observe PER2 impinging on phase and amplitude of rhythmic nuclear receptor target gene expression; for example, Bmal1 and $H n f 1 \alpha$ (Figs. 3B-D, 4A; Supplemental Fig. 3A). 
Glucose is produced in hepatic cells by either gluconeogenesis or the catabolism of glycogen. The circadian oscillator also appears to temporally orchestrate these two pathways (Panda et al. 2002; Storch et al. 2002) via E-box elements and nuclear receptor elements (NREs) (Fig. 7). Our results suggest that PER2 can act on both regulatory mechanisms, which allows a precise coupling. In particular, PER2 appears to act on the Pepck1 gene via its interaction with BMAL1 and CLOCK (Fig. 6A). This notion is based on our observation that expression of Pepck1 mRNA is affected in the various genotypes in a similar manner as the E-box-driven Per1 gene (Figs. 4C, 6A). In contrast, $H n f 1 \alpha$ or G6Pase expression profiles are different and appear to be affected by interaction of PER2 with nuclear receptors (Figs. 3D, 6B; Supplemental Figs.

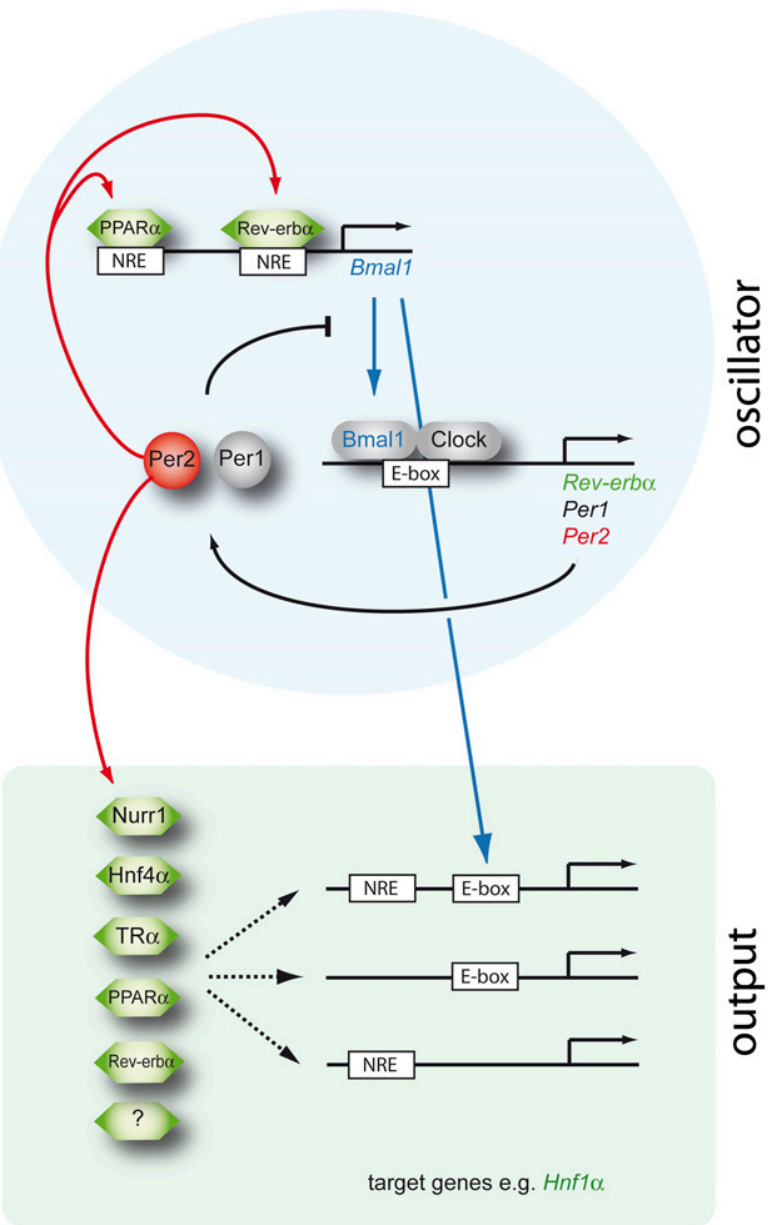

Figure 7. Model of how PER2 may couple E-box-driven and nuclear receptor-regulated gene expression. In the oscillator, both PER proteins act as repressors of E-box-mediated circadian transcription via interaction with BMAL1 and CLOCK. In addition, PER2 can modulate NRE-mediated transcription via interaction with nuclear receptors. This affects expression of Bmal1 in the oscillator and target genes in the output such as Hnf $1 \alpha$ may be regulated. These output targets can be modulated via E-boxes, NREs, or both. PER2-nuclear receptor interactions may be involved in this regulatory process (hatched arrows) to coordinate clock output processes.
3A, 6A) such as, for example, HNF4 $\alpha$. Future studies will show how post-translational modifications on PER2 impinge on E-box- and/or NRE-mediated transcription, and how PER2 contributes to the glycogen accumulation phenotype observed in Rev-Erb $\alpha^{-1-}$ Per2 mutant mice.

In summary, our findings reveal a novel, fast-responding mechanism of regulation in the circadian oscillator that is based on protein-protein interactions with PER2 as a coregulator of nuclear receptors. In this way, the regulatory potential of PER2 may be extended to link E-boxand NRE-regulated pathways (Fig. 7). If coupling of such pathways is interrupted, coordination of metabolism may be affected and fitness of the organism may be reduced. This might point toward novel strategies to suppress malignant growth and treatment of diseases rooted in the circadian system.

\section{Materials and methods}

\section{Plasmids}

Full-length mouse cDNAs encoding PER2, PER1, CRY1, REV$\mathrm{ERB} \alpha, \mathrm{ROR} \alpha, \mathrm{ER} \alpha, \mathrm{NURR} 1, \mathrm{PPAR} \alpha, \mathrm{HNF} 4 \alpha, \mathrm{RXR} \alpha$, and $\mathrm{THR} \alpha$ were fused in-frame to either two $\mathrm{N}$-terminal HA tags or two C-terminal V5 tags. For accession numbers, vectors, mutations, and oligonucleotides, see Supplemental Tables 1 and 2. To obtain Rev-Erb $\alpha$ luciferase, a 6.6-kb fragment of the mRev-Erb $\alpha$ gene, starting at the unique MluI restriction enzyme site $(\sim 3.5 \mathrm{~kb}$ upstream of the transcriptional start site) to the beginning of exon 2, was modified at the 3 ' site and cloned into the pGL3 basic vector (Promega). This constructs expresses, after appropriate splicing, an in-frame fusion protein containing the first 16 amino acids of mREV-ERB $\alpha$ and the firefly luciferase. The Bmal1 luc construct was from Nagoshi et al. (2004). The longer Bmal1 luciferase construct (Bmal1 ext. luc) refers to a $5^{\prime}$ extension of Bmal1 luc by 822 additional base pairs to include the PPAR $\alpha$ regulatory site (Canaple et al. 2006).

\section{Real-time bioluminescence monitoring}

Proliferating NIH 3T3 cells cultured in DMEM High Glucose (Sigma-Aldrich) supplemented with $10 \%$ fetal calf serum and $100 \mathrm{U} / \mathrm{mL}$ penicillin/streptomycin (Amimed) were transfected with $0.1 \mu \mathrm{g}$ of $p S E A P, 1.8 \mu \mathrm{g}$ of the luciferase reporter constructs, and the indicated amounts of expression vectors using JetPEI (Polyplus Transfection) in $35-\mathrm{mm}$ culture dishes. Cells were synchronized $48 \mathrm{~h}$ after transfection by addition of DMEM containing $100 \mathrm{nM}$ dexamethasone (Balsalobre et al. 2000). After $20 \mathrm{~min}$, the medium was changed to phenol red-free DMEM supplemented with $0.1 \mathrm{mM}$ luciferin and $5 \%$ fetal calf serum. Bioluminescence was monitored continuously and was analyzed using LumiCycle analysis software (Actimetrics). Raw data were normalized to SEAP activity (Roche Applied Science) in a culture medium sample taken before synchronization as transfection control.

\section{Coimmunoprecipitation analysis using} V5- and HA-tagged proteins

$\mathrm{NIH} 3 \mathrm{~T} 3$ cells were transfected in 10-cm dishes using linear polyethylenimine (LINPEI25; Polysciences Europe). The amounts of expression vectors were adjusted to yield comparable levels of expressed protein. Forty-eight hours after transfection, cells were harvested and nuclear extracts were prepared (see the 
Supplemental Material) and adjusted to a final salt concentration of $150 \mathrm{mM} \mathrm{NaCl}$. Twenty micrograms of nuclear protein extract in $250 \mu \mathrm{L}$ of lysis puffer with $150 \mathrm{mM} \mathrm{NaCl}$ and $0.1 \%$ Triton $\mathrm{X}-100$ were incubated with $15 \mu \mathrm{L}$ of $\alpha \mathrm{HA}$ agarose (SigmaAldrich) overnight at $4{ }^{\circ} \mathrm{C}$. Beads were collected by centrifugation and washed four times with lysis buffer supplemented with $1 \%$ Triton X-100 and $150 \mathrm{mM} \mathrm{NaCl}$. Samples were boiled and subjected to SDS-PAGE.

\section{Protein extraction and Western blot analysis}

Mouse liver nuclei were purified according to Ripperger et al. (2000). Nuclear extracts were prepared according to the NUN procedure (Lavery and Schibler 1993). SDS-PAGE and Western blot analysis were performed according to standard protocols. Antibodies used were rabbit PER1, PER2, CRY1, BMAL1, CLOCK, REV-ERB $\alpha$ (Preitner et al. 2002); PPAR $\alpha$ (Cayman); ROR $\alpha$ (Abcam), RNA POLII (Bethyl); HNF4 $\alpha$ (a gift from U. Schibler); rat HA (Roche Applied Science); and mouse V5 (Sigma-Aldrich).

\section{Coimmunoprecipitation analysis using liver nuclear extracts}

For coimmunoprecipitation experiments with mouse liver nuclear extracts, $200 \mu \mathrm{g}$ of nuclear extract were incubated in rotation overnight at $4^{\circ} \mathrm{C}$ with the indicated antibody and captured with protein A agarose beads (Roche Applied Science) for $2 \mathrm{~h}$ at $4^{\circ} \mathrm{C}$. The beads were washed according to Asher et al. (2008). After four washes, beads were resuspended in $2 \%$ SDS $/ 10 \%$ glycerol in $63 \mathrm{mM}$ Tris- $\mathrm{HCl}(\mathrm{pH} 6.8)$, and proteins were eluted for $15 \mathrm{~min}$ at room temperature. DTT was added to a concentration of $10 \mathrm{mM}$ to the eluate, and the samples were boiled and subjected to SDS-PAGE.

\section{ChIP}

Liver tissue $(\sim 1 \mathrm{~g})$ was homogenized in $1 \times$ PBS with $1 \%$ formaldehyde. The cross-linking was continued for $5 \mathrm{~min}$ at room temperature. The procedure of chromatin preparation, immunoprecipitation of cross-linked DNA fragments, the washing conditions, the reversal of the cross-links, the antibodies used, and the quantification of the DNA fragments by real-time PCR were described already in Ripperger and Schibler (2006). The real-time PCR probes are listed in Supplemental Table 3.

\section{RNA extraction, reverse transcription,} and real-time PCR detection

Total RNA was extracted from cells and liver tissue using RNABee (AMS Biotechnology) according to the manufacturer's instructions. Liver RNA was precipitated in $4 \mathrm{M} \mathrm{LiCl}$ to remove glycogen, and was purified further by phenol:chloroform extraction and ethanol precipitation. ssDNA complementary to the RNA starting from hybridized random hexamer primers was synthesized with SuperScript II (Life Technology Corporation) according to the manufacturer's instructions. Real-time PCR probes have been described (Supplemental Table 3; Preitner et al. 2002). All RNA samples were normalized to Gapdh mRNA accumulation. Relative mRNA levels were assessed by defining the highest value of each experiment in wild-type animals as $100 \%$.

\section{Animals}

Animal care and handling was performed according to the Canton of Fribourg's law for animal protection authorized by the Office Veterinaire Cantonal de Fribourg. We crossed Per2 ${ }^{\text {Brdm1 } 1}$ mice (Zheng et al. 1999) with Rev-Erb $\alpha$ knockout animals
(Preitner et al. 2002). The genotype of the offspring was determined by PCR (see Supplemental Table 3).

\section{Locomotor activity monitoring}

Mice housing and handling was performed as described (Jud et al. 2005). Activity records are double-plotted so that each day cycle's activity is plotted both to the right and below that of the previous cycle. We used the Clocklab software (Actimetrics) for wheel-running data acquisition and analysis. The freerunning period length during the first 5-7 $\mathrm{d}$ in constant darkness was calculated by $\chi^{2}$ periodogram analysis.

\section{In situ hybridization}

Specimen preparation, ${ }^{35}$ S-UTP-labeled riboprobe synthesis, and hybridization steps were performed as described (Albrecht et al. 1997). The in situ hybridization probes for Per1 (Albrecht et al. 1997) and for Bmal1 and Cry1 (Oster et al. 2002) are described. Quantification was performed according to Oster et al. (2002) using the Quantity One 1-D analysis software (Bio-Rad). We assessed the "relative mRNA abundance" values by defining the highest value of each experiment in wild-type animals as $100 \%$.

\section{Liver glycogen determination}

Liver pieces were weighted and adjusted with $2 \mathrm{M}$ hydrochloric acid to a final concentration of $0.1 \mathrm{mg} / \mu \mathrm{L}$ (Lamia et al. 2008). After sonication, samples were boiled for $3 \mathrm{~h}$ with constant agitation to convert glycogen in glucose and glucose 6-phosphate. The solution was neutralized with an equal volume of $2 \mathrm{M}$ $\mathrm{NaOH}$ and 8 vol of $100 \mathrm{mM}$ Tris (pH 7.4). Glucose was determined using the glucose-hexokinase kit (Sigma-Aldrich).

\section{PAS staining}

Small pieces of the liver were dissected and fixed in $4 \%$ paraformaldehyde in $1 \times$ PBS. Specimens were dehydrated, embedded in paraffin, and sectioned to $4-\mu \mathrm{m}$ thickness. Sections were stained with periodic acid-Schiff's method to demonstrate carbohydrates, and were counterstained with Mayer's hematoxylin solution (Sigma-Aldrich) according to the manufacturer's instructions.

\section{Measurement of enzymatic activities}

Liver homogenates were prepared in ice-cold $100 \mathrm{mM}$ Tris (pH 7.5), $0.25 \mathrm{M}$ sucrose, $5 \mathrm{mM}$ EDTA, and $1 \mathrm{mM}$ PMSF and centrifuged at $10,500 \mathrm{~g}$ for $20 \mathrm{~min}$. The supernatant was centrifuged further at $100,000 \mathrm{~g}$ for $1 \mathrm{~h}$. The resulting supernatant (cytosol) was collected and stored at $-70^{\circ} \mathrm{C}$ until PEPCK assay. The resulting pellet (microsomes) was resuspended in $100 \mathrm{mM}$ Na-cacodylate $(\mathrm{pH} 6.5) / 10 \%$ glycerol and stored at $-70^{\circ} \mathrm{C}$ until G6Pase assay. Total protein of the two fractions was determined using a BCA protein assay kit (Sigma-Aldrich). PEPCK activity was measured at $30^{\circ} \mathrm{C}$ as described by Petrescu et al. (1979). Briefly, phosphoenolpyruvate was carboxylated by PEPCK to form oxalacetate, which was converted further to malate using malic dehydrogenase. This conversion was monitored as decrease of NADH. Activity was expressed as milliunits per milligram of protein in liver supernatant $(1 \mathrm{mU}=1 \mathrm{nmol}$ of oxalacetate produced per minute). G6Pase activity was assayed according to Nordlie and Arion (1966). Activity was expressed as milliunits per milligram of protein in the microsomes $(1 \mathrm{mU}=1$ nmol of anorganic phosphate released per minute). 


\section{Statistical analysis}

Statistical analysis of all experiments was performed using Prism4 software (GraphPad Software, Inc.). Significant differences between groups were determined using one- or two-way ANOVA, followed by Bonferroni's post-test. Values were considered significantly different with $P<0.05\left({ }^{\star}\right), P<0.01\left(^{\star \star}\right)$, or $P<0.001\left(^{\star \star \star}\right)$.

\section{Acknowledgments}

We thank A. Hayoz, O. Pythoud, G. Bulgarelli, and A. Sargsyan for technical assistance, and Dr. Ueli Schibler for reagents. This work was supported by the Swiss National Science Foundation, the State of Fribourg, and the 6th EU framework program EUCLOCK.

\section{References}

Albrecht U, Sun ZS, Eichele G, Lee CC. 1997. A differential response of two putative mammalian circadian regulators, mper1 and mper2, to light. Cell 91: 1055-1064.

Albrecht U, Bordon A, Schmutz I, Ripperger J. 2007. The multiple facets of Per2. Cold Spring Harb Symp Quant Biol 72: 95-104.

Asher G, Gatfield D, Stratmann M, Reinke H, Dibner C, Kreppel F, Mostoslavsky R, Alt FW, Schibler U. 2008. SIRT1 regulates circadian clock gene expression through PER2 deacetylation. Cell 134: 317-328.

Bae K, Jin X, Maywood ES, Hastings MH, Reppert SM, Weaver DR. 2001. Differential functions of mPer1, mPer2, and mPer3 in the SCN circadian clock. Neuron 30: 525-536.

Balsalobre A, Brown SA, Marcacci L, Tronche F, Kellendonk C, Reichardt HM, Schutz G, Schibler U. 2000. Resetting of circadian time in peripheral tissues by glucocorticoid signaling. Science 289: 2344-2347.

Bunger MK, Wilsbacher LD, Moran SM, Clendenin C, Radcliffe LA, Hogenesch JB, Simon MC, Takahashi JS, Bradfield CA. 2000. Mop3 is an essential component of the master circadian pacemaker in mammals. Cell 103: 1009-1017.

Canaple L, Rambaud J, Dkhissi-Benyahya O, Rayet B, Tan NS, Michalik L, Delaunay F, Wahli W, Laudet V. 2006. Reciprocal regulation of brain and muscle Arnt-like protein 1 and peroxisome proliferator-activated receptor $\alpha$ defines a novel positive feedback loop in the rodent liver circadian clock. Mol Endocrinol 20: 1715-1727.

Cermakian N, Monaco L, Pando MP, Dierich A, Sassone-Corsi P. 2001. Altered behavioral rhythms and clock gene expression in mice with a targeted mutation in the Period1 gene. EMBO J 20: 3967-3974.

DeBruyne JP, Weaver DR, Reppert SM. 2007a. CLOCK and NPAS2 have overlapping roles in the suprachiasmatic circadian clock. Nat Neurosci 10: 543-545.

DeBruyne JP, Weaver DR, Reppert SM. 2007b. Peripheral circadian oscillators require CLOCK. Curr Biol 17: R538-R539. doi: 10.1016/j.cub.2007.05.067.

Downes M, Burke LJ, Bailey PJ, Muscat GE. 1996. Two receptor interaction domains in the corepressor, N-CoR/RIP13, are required for an efficient interaction with Rev-erbA $\alpha$ and RVR: Physical association is dependent on the E region of the orphan receptors. Nucleic Acids Res 24: 4379-4386.

Gekakis N, Staknis D, Nguyen HB, Davis FC, Wilsbacher LD, King DP, Takahashi JS, Weitz CJ. 1998. Role of the CLOCK protein in the mammalian circadian mechanism. Science 280: 1564-1569.

Griffin EA Jr, Staknis D, Weitz CJ. 1999. Light-independent role of CRY1 and CRY2 in the mammalian circadian clock. Science 286: 768-771.
Hardin PE, Hall JC, Rosbash M. 1990. Feedback of the Drosophila period gene product on circadian cycling of its messenger RNA levels. Nature 343: 536-540.

Harding HP, Lazar MA. 1993. The orphan receptor Rev-ErbA $\alpha$ activates transcription via a novel response element. Mol Cell Biol 13: 3113-3121.

Harding HP, Lazar MA. 1995. The monomer-binding orphan receptor Rev-Erb represses transcription as a dimer on a novel direct repeat. Mol Cell Biol 15: 4791-4802.

Heery DM, Kalkhoven E, Hoare S, Parker MG. 1997. A signature motif in transcriptional co-activators mediates binding to nuclear receptors. Nature 387: 733-736.

Hennig S, Strauss HM, Vanselow K, Yildiz O, Schulze S, Arens J, Kramer A, Wolf E. 2009. Structural and functional analyses of PAS domain interactions of the clock proteins Drosophila PERIOD and mouse PERIOD2. PLOS Biol 7: e94. doi: 10.1371/journal.pbio.1000094.

Hogenesch JB, Gu YZ, Jain S, Bradfield CA. 1998. The basichelix-loop-helix-PAS orphan MOP3 forms transcriptionally active complexes with circadian and hypoxia factors. Proc Natl Acad Sci 95: 5474-5479.

Hu X, Lazar MA. 1999. The CoRNR motif controls the recruitment of corepressors by nuclear hormone receptors. Nature 402: 93-96.

Jin X, Shearman LP, Weaver DR, Zylka MJ, de Vries GJ, Reppert SM. 1999. A molecular mechanism regulating rhythmic output from the suprachiasmatic circadian clock. Cell 96: 57-68.

Jud C, Schmutz I, Hampp G, Oster H, Albrecht U. 2005. A guideline for analyzing circadian wheel-running behavior in rodents under different lighting conditions. Biol Proced Online 7: 101-116.

King DP, Zhao Y, Sangoram AM, Wilsbacher LD, Tanaka M, Antoch MP, Steeves TD, Vitaterna MH, Kornhauser JM, Lowrey PL, et al. 1997. Positional cloning of the mouse circadian clock gene. Cell 89: 641-653.

Kume K, Zylka MJ, Sriram S, Shearman LP, Weaver DR, Jin X, Maywood ES, Hastings MH, Reppert SM. 1999. mCRY1 and mCRY2 are essential components of the negative limb of the circadian clock feedback loop. Cell 98: 193-205.

Lamia KA, Storch KF, Weitz CJ. 2008. Physiological significance of a peripheral tissue circadian clock. Proc Natl Acad Sci 105: 15172-15177.

Lavery DJ, Schibler U. 1993. Circadian transcription of the cholesterol $7 \alpha$ hydroxylase gene may involve the liverenriched bZIP protein DBP. Genes \& Dev 7: 1871-1884.

Lee C, Etchegaray JP, Cagampang FR, Loudon AS, Reppert SM. 2001. Posttranslational mechanisms regulate the mammalian circadian clock. Cell 107: 855-867.

Le Martelot G, Claudel T, Gatfield D, Schaad O, Kornmann B, Sasso GL, Moschetta A, Schibler U. 2009. REV-ERB $\alpha$ participates in circadian SREBP signaling and bile acid homeostasis. PLOS Biol 7: e1000181. doi: 10.1371/journal.pbio.1000181.

Liu AC, Lewis WG, Kay SA. 2007. Mammalian circadian signaling networks and therapeutic targets. Nat Chem Biol 3: 630-639.

Liu AC, Tran HG, Zhang EE, Priest AA, Welsh DK, Kay SA. 2008. Redundant function of REV-ERB $\alpha$ and $\beta$ and nonessential role for Bmall cycling in transcriptional regulation of intracellular circadian rhythms. PLoS Genet 4: e1000023. doi: 10.1371/journal.pgen.1000023.

Nagoshi E, Saini C, Bauer C, Laroche T, Naef F, Schibler U. 2004. Circadian gene expression in individual fibroblasts: Cell-autonomous and self-sustained oscillators pass time to daughter cells. Cell 119: 693-705.

Nordlie RC, Arion WJ. 1966. Glucose-6-phosphatase. Methods Enzymol 9: 619-625. 
Oster H, Yasui A, van der Horst GT, Albrecht U. 2002. Disruption of mCry2 restores circadian rhythmicity in mPer2 mutant mice. Genes \& Dev 16: 2633-2638.

Oster H, Baeriswyl S, Van Der Horst GT, Albrecht U. 2003. Loss of circadian rhythmicity in aging $\mathrm{mPer}^{-1-} \mathrm{mCry} 2^{-1-} \mathrm{mu}-$ tant mice. Genes \& Dev 17: 1366-1379.

Panda S, Antoch MP, Miller BH, Su AI, Schook AB, Straume M, Schultz PG, Kay SA, Takahashi JS, Hogenesch JB. 2002. Coordinated transcription of key pathways in the mouse by the circadian clock. Cell 109: 307-320.

Petrescu I, Bojan O, Saied M, Barzu O, Schmidt F, Kuhnle HF. 1979. Determination of phosphoenolpyruvate carboxykinase activity with deoxyguanosine $5^{\prime}$-diphosphate as nucleotide substrate. Anal Biochem 96: 279-281.

Preitner N, Damiola F, Lopez-Molina L, Zakany J, Duboule D, Albrecht U, Schibler U. 2002. The orphan nuclear receptor REV-ERB $\alpha$ controls circadian transcription within the positive limb of the mammalian circadian oscillator. Cell 110: 251-260.

Raghuram S, Stayrook KR, Huang P, Rogers PM, Nosie AK, McClure DB, Burris LL, Khorasanizadeh S, Burris TP, Rastinejad F. 2007. Identification of heme as the ligand for the orphan nuclear receptors REV-ERB $\alpha$ and REV-ERB $\beta$. Nat Struct Mol Biol 14: 1207-1213.

Reick M, Garcia JA, Dudley C, McKnight SL. 2001. NPAS2: An analog of clock operative in the mammalian forebrain. Science 293: 506-509.

Ripperger JA, Schibler U. 2006. Rhythmic CLOCK-BMAL1 binding to multiple E-box motifs drives circadian Dbp transcription and chromatin transitions. Nat Genet 38: 369-374.

Ripperger JA, Shearman LP, Reppert SM, Schibler U. 2000. CLOCK, an essential pacemaker component, controls expression of the circadian transcription factor DBP. Genes \& Dev 14: 679-689.

Rudic RD, McNamara P, Curtis AM, Boston RC, Panda S, Hogenesch JB, Fitzgerald GA. 2004. BMAL1 and CLOCK, two essential components of the circadian clock, are involved in glucose homeostasis. PLOS Biol 2: e377. doi: 10.1371/journal.pbio.0020377.

Sato TK, Panda S, Miraglia LJ, Reyes TM, Rudic RD, McNamara P, Naik KA, FitzGerald GA, Kay SA, Hogenesch JB. 2004. A functional genomics strategy reveals Rora as a component of the mammalian circadian clock. Neuron 43: 527-537.

Savkur RS, Burris TP. 2004. The coactivator LXXLL nuclear receptor recognition motif. J Pept Res 63: 207-212.

Shearman LP, Zylka MJ, Weaver DR, Kolakowski LF Jr, Reppert SM. 1997. Two period homologs: Circadian expression and photic regulation in the suprachiasmatic nuclei. Neuron 19: 1261-1269.

Shearman LP, Sriram S, Weaver DR, Maywood ES, Chaves I, Zheng B, Kume K, Lee CC, van der Horst GT, Hastings MH, et al. 2000. Interacting molecular loops in the mammalian circadian clock. Science 288: 1013-1019.

Storch KF, Lipan O, Leykin I, Viswanathan N, Davis FC, Wong WH, Weitz CJ. 2002. Extensive and divergent circadian gene expression in liver and heart. Nature 417: 78-83.

Sun ZS, Albrecht U, Zhuchenko O, Bailey J, Eichele G, Lee CC. 1997. RIGUI, a putative mammalian ortholog of the Drosophila period gene. Cell 90: 1003-1011.

Tei H, Okamura H, Shigeyoshi Y, Fukuhara C, Ozawa R, Hirose M, Sakaki Y. 1997. Circadian oscillation of a mammalian homologue of the Drosophila period gene. Nature 389: 512516.

Tian JM, Schibler U. 1991. Tissue-specific expression of the gene encoding hepatocyte nuclear factor 1 may involve hepatocyte nuclear factor 4. Genes \& Dev 5: 2225-2234.
Ueda HR, Chen W, Adachi A, Wakamatsu H, Hayashi S, Takasugi T, Nagano M, Nakahama K, Suzuki Y, Sugano S, et al. 2002. A transcription factor response element for gene expression during circadian night. Nature 418: 534-539.

Ueda HR, Hayashi S, Chen W, Sano M, Machida M, Shigeyoshi Y, Iino M, Hashimoto S. 2005. System-level identification of transcriptional circuits underlying mammalian circadian clocks. Nat Genet 37: 187-192.

Woo EJ, Jeong DG, Lim MY, Jun Kim S, Kim KJ, Yoon SM, Park BC, Eon Ryu S. 2007. Structural insight into the constitutive repression function of the nuclear receptor Rev-erb $\beta$. I Mol Biol 373: 735-744.

Yamagata K, Furuta H, Oda N, Kaisaki PJ, Menzel S, Cox NJ, Fajans SS, Signorini S, Stoffel M, Bell GI. 1996a. Mutations in the hepatocyte nuclear factor- $4 \alpha$ gene in maturity-onset diabetes of the young (MODY1). Nature 384: 458-460.

Yamagata K, Oda N, Kaisaki PJ, Menzel S, Furuta H, Vaxillaire M, Southam L, Cox RD, Lathrop GM, Boriraj VV, et al. 1996b. Mutations in the hepatocyte nuclear factor- $1 \alpha$ gene in maturity-onset diabetes of the young (MODY3). Nature 384: 455-458.

Yang X, Downes M, Yu RT, Bookout AL, He W, Straume M, Mangelsdorf DJ, Evans RM. 2006. Nuclear receptor expression links the circadian clock to metabolism. Cell 126: 801810.

Yin L, Lazar MA. 2005. The orphan nuclear receptor Rev-erb $\alpha$ recruits the $\mathrm{N}-\mathrm{CoR} /$ histone deacetylase 3 corepressor to regulate the circadian Bmall gene. Mol Endocrinol 19: 1452-1459.

Yin L, Wu N, Curtin JC, Qatanani M, Szwergold NR, Reid RA, Waitt GM, Parks DI, Pearce KH, Wisely GB, et al. 2007. Reverb $\alpha$, a heme sensor that coordinates metabolic and circadian pathways. Science 318: 1786-1789.

Zheng B, Larkin DW, Albrecht U, Sun ZS, Sage M, Eichele G, Lee CC, Bradley A. 1999. The mPer2 gene encodes a functional component of the mammalian circadian clock. Nature 400: $169-173$.

Zheng B, Albrecht U, Kaasik K, Sage M, Lu W, Vaishnav S, Li Q, Sun ZS, Eichele G, Bradley A, et al. 2001. Nonredundant roles of the mPer1 and mPer2 genes in the mammalian circadian clock. Cell 105: 683-694. 


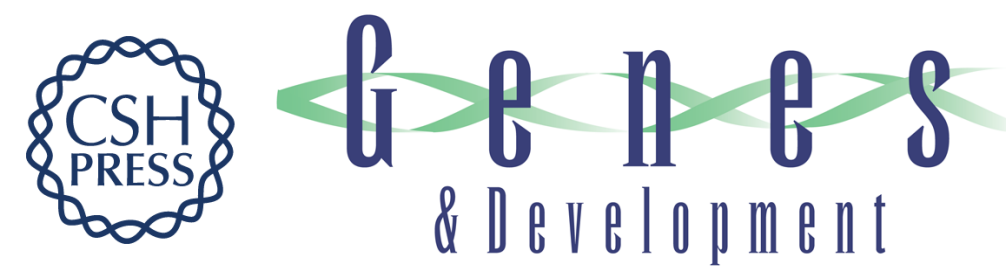

\section{The mammalian clock component PERIOD2 coordinates circadian output by interaction with nuclear receptors}

Isabelle Schmutz, Jürgen A. Ripperger, Stéphanie Baeriswyl-Aebischer, et al.

Genes Dev. 2010, 24:

Access the most recent version at doi:10.1101/gad.564110

\section{Supplemental http://genesdev.cshlp.org/content/suppl/2010/01/26/24.4.345.DC1 \\ Material}

Related Content A wheel of time: the circadian clock, nuclear receptors, and physiology Xiaoyong Yang

Genes Dev. April , 2010 24: 741-747

References This article cites 60 articles, 17 of which can be accessed free at:

http://genesdev.cshlp.org/content/24/4/345.full.html\#ref-list-1

Articles cited in:

http://genesdev.cshlp.org/content/24/4/345.full.html\#related-urls

\section{License}

Email Alerting

Service

Receive free email alerts when new articles cite this article - sign up in the box at the top right corner of the article or click here.

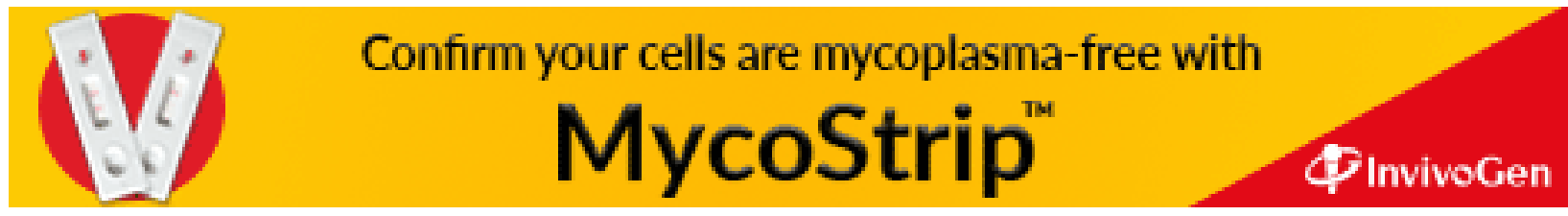

